TEODORA Z. MLADENOVIĆ

Lebane, Serbia

E-mail: teodoramladenovic@hotmail.com
904:59(497.11)"14"

904:725.963(497.11)"14"

902.2(497.11)"2008”

COBISS.SR-ID 254098956

Original research article

Received: May $15^{\text {th }} 2017$

Accepted: October 31 2017

\title{
FAUNAL REMAINS FROM FORTIFIED MEDIEVAL CASTLE AT THE KULINA-SOLOTUŠA SITE (WESTERN SERBIA)
}

\begin{abstract}
Two archaeological campaigns were carried out during 2007 and 2008 at fortified castle at the Kulina-Solotuša site, dating from 15th century, placed on the eastern slopes of Tara mountain. This paper presents the results of archaeozoological analysis of faunal material collected during 2008 campaign in squares B1-B9 and V1. Domestic animals outnumber wild species. The most important among them are cattle, sheep, goats and pigs, while the remains of horses, dogs and domestic fowl are far less present. The game consists of wild boar, red deer, roe deer, brown bear and hare. Age of animals, fragmentation and the presence of a large number of butchery traces indicate that most of the animal bones are remains of food.
\end{abstract}

KEYWORDS: FAUNAL REMAINS, MEDIEVAL CASTLE, SOLOTUŠA, ANIMAL HUSBANDRY, HUNTING, DIET STRATEGY.

\section{INTRODUCTION $^{1}$}

Archaological site Kulina is located in the village of Solotuša, on the eastern slopes of Tara mountain, 10 km south-west of Bajina Bašta (Fig. $1)$. The fortress is located on a very inaccessible point, at the top of the hill which slopes steeply toward the Solotuška river, at $830 \mathrm{~m}$ above sea level (Дероко 1950: 150). The most accessible approach is from the south and south-east, because on the west, north and east castle is surrounded by steep cliffs. Archaeological excavation were carried out during 2007 and 2008, conducted by

1 This paper presents a summary and a corrected version of the final thesis, defended on September 30, 2014, at the Department of Archeology, Faculty of Philosophy, University of Belgrade. I wish to express my gratitude to professor Dr Vesna Dimitrijević for helping me in preparation of this work, and assistant professor Dr Dejan Radičević for giving me opportunity to work with faunal material from Kulina-Solotuša site.
Dr Đorđe Janković. The team consisted of Pero Praštalo, MA, manager of field work, and archaeologists Sanja Crnobrnja and Dragan Milanović (Јанковић и Праштало, 2007). The castle ground plan is of approximated trapezoidal shape, measuring $20 \times 30 \mathrm{~m}$. The walls were built of halfdressed stone filled with rubble, and their thickness is $1.20-1.70 \mathrm{~m}$. In the south-eastern corner of the building is a circular tower, joined with the mass of the walls.

The interior of the castle is divided into squares (4x4 m) (Fig. 2). The excavations in 2007 started at the northern part, i.e. chamber A, whose area is $96 \mathrm{~m}^{2}$. On this occasion, eastern part of the chamber was excavated to the end, while the western part was researched to the floor level. Vertical stratigraphy has shown that under a layer of rubble, formed by the demolition of the walls, is a cultural layer (0.10 to $0.20 \mathrm{~m}$ thickness) which is, 


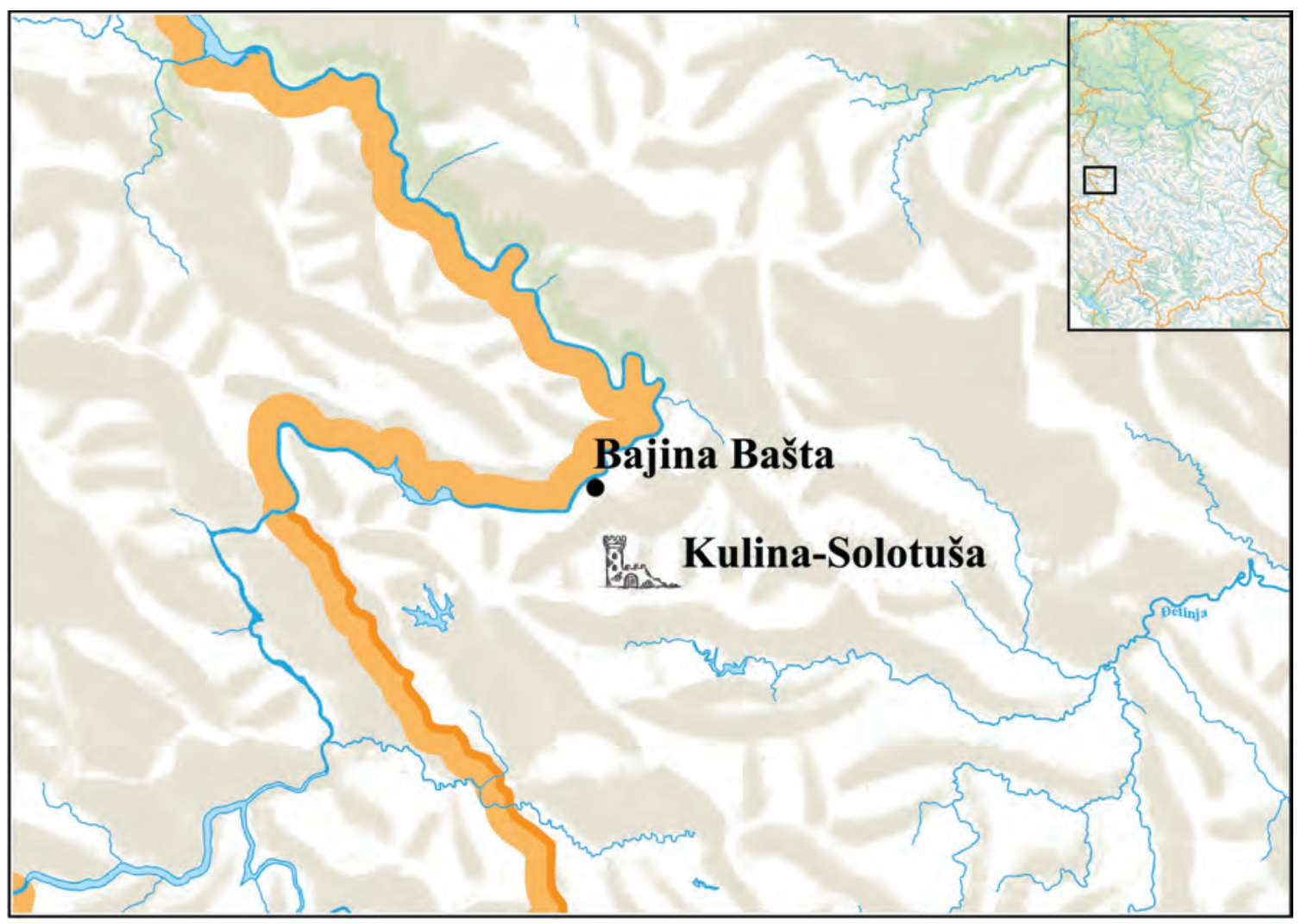

Fig. 1 Geographical position of Kulina-Solotuša site.

on the basis of the archaeological material, dated to the $15^{\text {th }}$ century. The same year, the archaeological research of the south-western part of the castle has started, and in this location, similar vertical stratigraphy, types of findings and their chronology were recorded ${ }^{2}$. Archeological work continued in 2008, and the excavation of the the chamber A were completed. At the northeastern part, excavations of the chamber B were started, where a cistern with a well were detected, circular in section, built in dry-stone wall technique. In chamber $\mathrm{A}$, under a layer of the $15^{\text {th }}$ century, the early Byzantine walls were found. Similar walls were detected in the chamber $\mathrm{B}$, as well as in the southern part of fortification ${ }^{3}$. Since the archaeological excavation were not continued, early Byzantine walls are not completely defined, yet.

2 The excavation information for Kulina-Solotuša site was taken from field documentation for 2007 campaign.

3 The excavation information for Kulina-Solotuša site was taken from field documentation for 2008 campaign.

\section{MATERIALS AND METHODS}

The sample of faunal material, collected by hand during 2008 campaign in squares B1-B6 (chamber B with a cistern), B7-B9 (the eastern wall of the fortress and tower in the south-eastern corner) and V1 (eastern entrance to the fortified castle), has been analysed (Fig. 2).

Quantification is given by NISP (Number of Identified Specimens) and MNI (Minimal Number of Individuals). The Number of Identified Specimens includes all specimens attributed to particular taxon. The Minimal Number of Individuals was counted on the basis of the most frequent element of a particular taxon, combined with age and sex differences within the most frequent element.

Taxonomic identification of mammals and birds was carried out consulting relevant literature (Boessneck 1969; Schmid 1972; Prummel and Frisch 1986; Prummel 1988; Boyd et al. 1994; Cohen and Serjeantson 1996; Halstead, Collins 




Fig. 2 Castle ground plan with marked squares from which the analysed faunal sample comes from.

and Isaakidou 2002; Johnstone 2004; Budras et al. 2009; Frandson, Lee Wilke and Dee Fails 2009; Zeder and Lapham 2010; Zeder and Pilaar 2010), and based on comparison with specimens from the Archaeozoological Reference Collection of Laboratory for Bioarchaeology, Faculty of Philosophy in Belgrade.

Traces of taphonomic processes - weathering, gnawing, burning, and traces of anthropogenic activities were all recorded. The age determination was based on the time of eruption and attrition of teeth (Silver 1969; Hilson 2005), and the epiphysial fusion (Silver, 1969; Schmid, 1972). Since the bone epiphysis fuse at different age, the material was divided into three groups based on the age at which fusion generally occurs. The first 


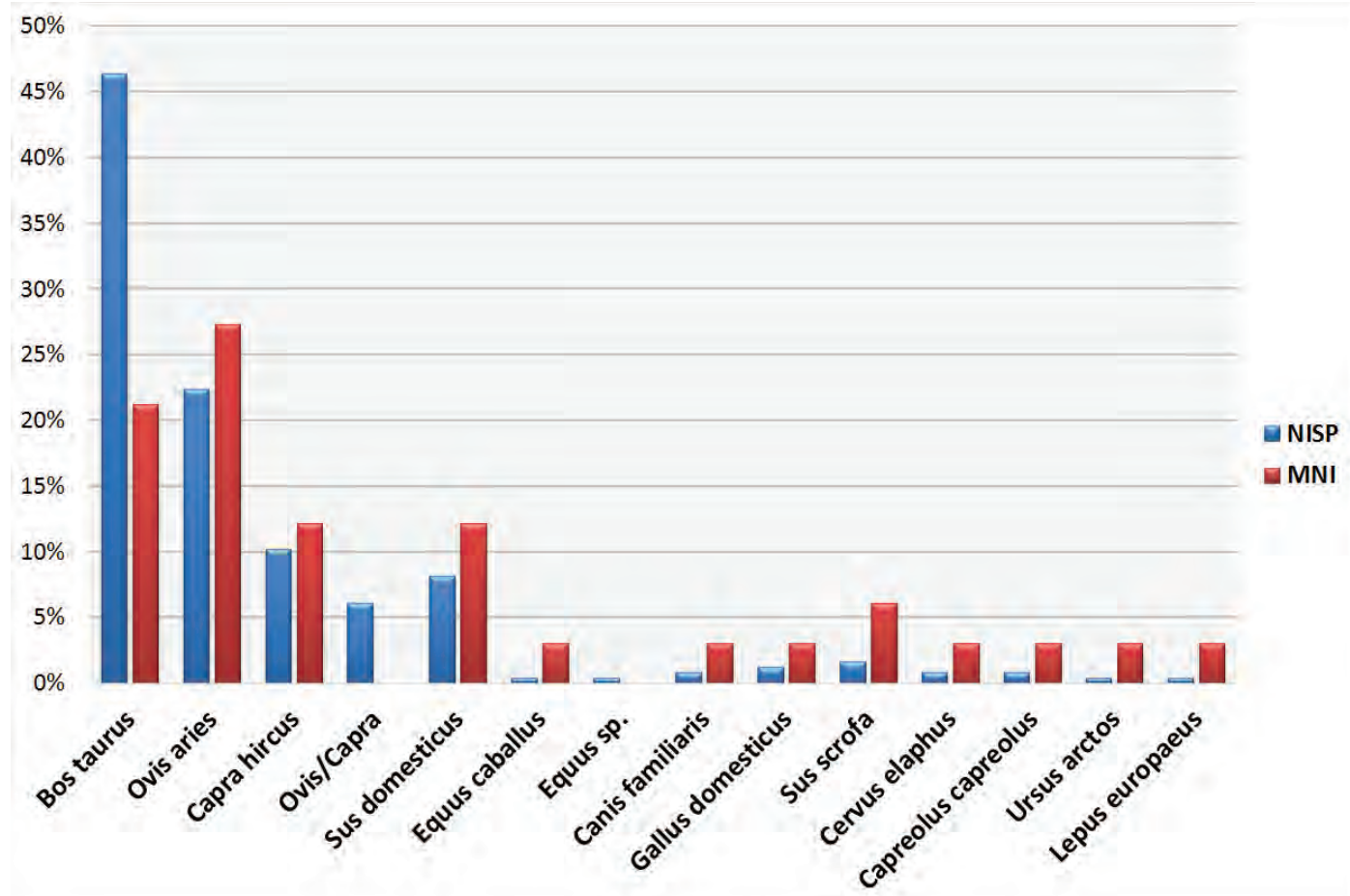

Fig. 3 Procentual distribution of various animal taxa expressed as NISP (number of identified specimens) and MNI (minimal number of individuals).

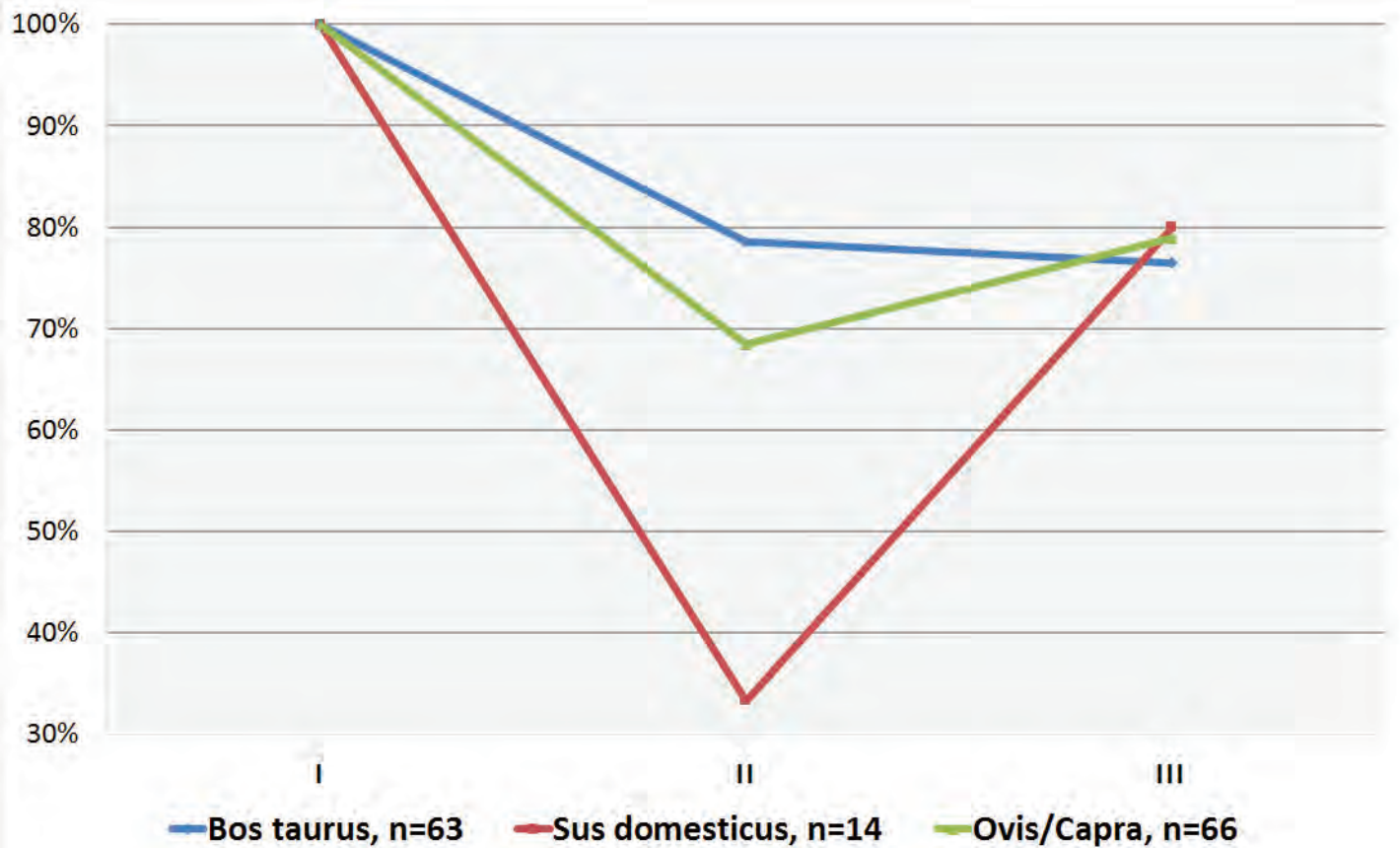

Fig. 4 Survivorship curves of cattle, sheep/goat and pig (I - 12 months of age at sheep, goat and pig and 24 months of age at cattle; II - 18 months of age at sheep and goat and 24 months of age at pig and cattle ; III - more than 36 months at sheep, goat and pig and more than 42 months of age at cattle).

group are bones which epiphysis fuse at juvenile fuse at subadult age, i.e, from the second to third age, which is around the first year in sheep, goats year in sheep, goats and pigs, and from the third and pigs, and around the second year in cattle. to fourth year in cattle. The third group consists The second group are the bones whose epiphysis of bones which epiphysis fuse at adult age (Reitz 
and Wing 2008: 72, 194). Age structure, obtained on the basis of the degree of epiphysial fusion is expressed by the survivorship curve.

Measurements were taken following the standards from A. von den Driesch (1976). Withers heights for cattle were calculated using the factors given by Matolcsi (1970), for sheep and pig using Teichert (1975), for goat using Schramm (1967), and for dog using Harcourt (1974).

\section{FAUNAL COMPOSITION AND TAPHONOMY}

Out of 559 specimens, 246 were identified to the species level (44\%). Domestic animals (96\%) outnumber game (4\%). Domestic fauna consisted of: cattle (Bos taurus), sheep (Ovis aries), goats (Capra hircus), pigs (Sus domesticus), horses (Equus caballus), dogs (Canis familiaris) and domestic fowl (Gallus domesticus). Game included wild boar (Sus scrofa), red deer (Cervus elaphus), roe deer (Capreolus capreolus), brown bear (Ursus arctos) and hare (Lepus europaeus). Due to the high degree of fragmentation some of the specimens were identifed to the class level and they were placed into large-sized and medium-sized mammals categories (Table 1). Those were mainly small fragments of long bones, ribs and vertebral bones, which probably belonged to cattle, sheep, goat or pig, but could not be attributed to them certainly.

Based on the Number of Identified Specimens (NISP), the most frequent animals are cattle (46.3\%), followed by sheep and goats (38.6\%), pigs $(8.1 \%)$, and wild boar (1.6\%). According to the Minimal Number of Individuals, the most frequent animals are sheep and goat $(39.5 \%)$, followed by cattle (21.2\%), pig (12.2\%), wild boar (6.1\%) and other animal species (Fig. 3).

Bone fragmentatiton is highly present and it is the consequence of human activities such as animal butchery and breaking of the bones in order to obtain bone marrow. Whole bones represent only
$5 \%$ of the sample, and the most numerous being tarsal bones, followed by phalanges and patellae, because these bones are not suitable for processing and are not rich in meat.

Traces of weathering, caused by exposition to atmospheric influences before burying in the sediment, were present on $35.4 \%$ specimens. These are mostly slight cracking of the bone and foliation of the periosteum. That indicates that the bones were relatively quickly stored and that the chemical characteristics of sediments were suitable for the relatively good preservation of skeletal remains. Bones with burning traces at the ends are present and indicate the preparation of food, i.e. the baking, are represented in the material with $0.8 \%$. Traces of gnawing, mostly by dogs, were present on $33.3 \%$ of all identified specimens.

\begin{tabular}{|l|c|}
\hline Taxon & NISP \\
\hline Bos taurus & 114 \\
\hline Ovis aries & 55 \\
\hline Capra hircus & 25 \\
\hline Ovis/Capra & 15 \\
\hline Sus domesticus & 20 \\
\hline Equus caballus & 1 \\
\hline Equus sp. & 1 \\
\hline Canis familiaris & 2 \\
\hline Gallus domesticus & 3 \\
\hline Domestic animals, total & 236 \\
\hline Sus scrofa & 4 \\
\hline Cervus elaphus & 2 \\
\hline Ursus arctos & 1 \\
\hline Capreolus capreolus & 2 \\
\hline Lepus europaeus & 1 \\
\hline Wild animals, total & 10 \\
\hline Large-sized mammals & 80 \\
\hline Medium-sized mammals & 233 \\
\hline Faunal remains identified to the class level, total & 313 \\
\hline Total & $\mathbf{5 5 9}$ \\
\hline
\end{tabular}

Table 1 The distribution of various animal taxa expressed as NISP (number of identified specimens). 


\section{DOMESTIC ANIMALS}

\section{Cattle (Bos taurus)}

The cattle is the most frequent species among analyzed material. It represents $46.3 \%$ of the identified bones (Fig. 3), and at least 7 individuals were determined, according to MNI, based on right tibiae. The most numerous cattle body parts were tibiae, metapodial bones, tarsal bones, and mandibles. Based on morphology of pelvic bones, there are two female and one male individuals in faunal sample from Kulina-Solotuša site.

Based by time of eruption and attrition of teeth, it is assumed that adult cattle older than 3 or 4 years are predominantly present. Only one mandible belonged to a calf under two years of age. The epiphysial fusion shows that there is no specimen younger than 2 years. The most of the cattle were slaughtered as subadult or adult animals, probably because of longer exploitation of secondary products (Fig. 4).

Exostoses were noticed on volar side of one metacarpal bone, plantar side of six metatarsal bones and three calcanei. Since appearing on the metapodial and tarsal bones, but not being caused by the fracture of the bone, the reason of bone tissue accumulation could be consequence of burden overload, and/or weight of the individuals, which were probably used as working animals for agricultural work or towing.

More than half of the cattle bones $(60 \%)$ showed cutting or chopping marks, which are the most numerous on metapodial bones, mandibles and tibiae. Butchery marks are inflicted by cleavers, big and small knives during the disarticulation of a carcass, filleting, and skinning.

During the medieval period the trend of animal husbandry declines. This is mostly reflected in withers' height and type of cattle horns. The withers' height is about $30 \mathrm{~cm}$ lower than during the Roman period. In Europe, cattle mostly belonged to the small brachyceros type (withers' height about $112 \mathrm{~cm}$ ) with short and thin horns, and narrow, wavy frontal ridge (Bökönyi 1974: 134-136).
Based on the length of one metatarsal bone, the withers' height of cattle was calculated and its value is $78.3 \mathrm{~cm}$. This value is noticeably lower in regard to other medieval sites in Serbia where ranges from 111.23 to $119 \mathrm{~cm}$ (Блажић 1995: 343; Блажић 1999a: 36; Blažić 1999b: 443; Марковић 2015: 401).

\section{Sheep (Ovis aries) and goat (Capra hircus)}

Sheep and goats were the second numerous species (38.6\%) (Fig. 3). It is difficult, on the basis of osteological material, to distinguish sheep and goat, primarily because of the great similarity in the skeleton structure of these two species. Therefore, some of the specimens are classified as Ovis/ Capra (6\%). Sheep bones (22.4\%) are more numerous than goat bones (10.2\%). At least 9 sheep are present, according to MNI, based on right tibiae, and at least 4 goats, according to MNI, based on left radii. According to this parameter, sheep and goats were the most numerous species (39\%). Although they are often being kept together, these two species are distinguished, among other things, by the quality of the meat and secondary products, and it is important to separate their bones in the material, primarily due to the reconstruction of economic strategy (Davis 1987: 33).

Based on morphology of pelvic bone, there are two female sheep. Exostoses were noticed on medial side of distal part of one sheep's metatarsal bone.

Among sheep and goat specimens almost all body parts are present. The most numerous sheep bones are tibiae $(20 \%)$, scapulae $(12.7 \%)$, radii and mandibles (each by 9\%). The most frequent goat bones are radii (24\%), mandibles (16\%), tibiae, metacarpal bones and the 1st phalanges (each by $12 \%)$. The other parts of skeleton are present with less than $10 \%$.

Time of eruption and attrition of teeth shows that one sheep younger than a year is present and that the rest of the individuals are adult, while goat juveniles and individual older than 2 years are equally present (each by 2). Based by time of 
epiphysial fusion, there is no individual younger than a year. The most of sheep and goats are subadult or adult, suggesting that they have primarily been kept for dairy food and wool (Fig. 4).

Butchery marks were found on $41 \%$ of the bones, most of them on the long bones - tibiae, humeri, radii and metapodials. They are inflicted by knives and cleavers during the disarticulation of a carcass, portioning and filleting meat.

During the medieval period, withers' height of sheep also decreased and it differed throughout Europe. The average withers' height in Russia was $65 \mathrm{~cm}$ (Цалкин, 1956), $61 \mathrm{~cm}$ in Poland (Kubasiewicz i Gawlikowski, 1965), in Hungary under $59 \mathrm{~cm}$, in Central Europe between 54-64 cm, while in Western Europe ranged from 51-62 cm (Bökönyi, 1974). After the Copper age, sheep withers' height reached the lowest measures, it was about $5 \mathrm{~cm}$ lower as compared to the Roman period sheep. However, in the late middle Ages, during the $14^{\text {th }}$ and the $15^{\text {th }}$ century and onward, sheep become larger, what is confirmed in the Carpathian Basin. During the period from the $14^{\text {th }}$ to the $17^{\text {th }}$ century, increased the withers' height at about $70 \mathrm{~cm}$, which is the difference of $10 \mathrm{~cm}$, in comparison with the period from the $10^{\text {th }}$ to the $13^{\text {th }}$ century in Hungary (Bökönyi 1974: 188). During the middle Ages, the rams had thick, three-sided horns, and sheep had small, rudimentary horns (Bökönyi 1974: 181). Hornless sheep rarely occur, as well as those with horns rolled forward, almost horizontally. Pictured on the fresco painting, located on the south wall of the nave of the St. Demetrius church in Peć, painted between 13381346, in Nativity scene, shepherds with sheep and goats with different types of horns are shown (Théodoridès 1964: 387; Петковић 1982: 18).

Medieval goats are smaller than Roman, but, from the $14^{\text {th }}$ century, a noticeable increase in height is observed. Males tend to have large, twisted horns, although there were individuals without horns (Bökönyi 1974: 198-200).

The withers' height of sheep was calculated and its value is $61.4 \mathrm{~cm}$ (based on astragalus),
$62.7 \mathrm{~cm}$ (based on radii) and $60 \mathrm{~cm}$ (based on calcanei). Goat's withers' height based on radii is $67.2 \mathrm{~cm}$. The average withers' height of sheep and goats is similar comparing to other medieval sites in Serbia (Блажић 1999a: 38; Blažić 1999b: 444; Марковић 2015: 400).

\section{Pig (Sus domesticus)}

Pig bones were the third most common bone finds at the fortified medieval castle of Kulina-Solotuša site. It represents $8.1 \%$ of the identified bones (Fig. 3), and at least 4 individuals were determined, according to MNI, based on right tibiae. The most numerous pig's body parts are limb bones - humerus, ulna, radius, femur, tibia and metatarsal bones $(75 \%)$. An epigenetic modification was observed at one humerus - missing foramen in the fossa olecrani (Fig. 5).

Based on time of eruption and attrition of teeth, it is assumed that there are two individuals between 1 and 2 years of age, and two individuals older than 17 months. The epiphysial fusion data show that the majority of pigs were slaughtered in between their first and third years when the meat is of highest quality (Fig. 4). Presence of adult specimens shows that some pigs were kept longer for reproduction.

Half of the pig bones carried butchery marks, but they are the most numerous on tibiae and radii. They are inflicted by cleavers, big and small knives during the disarticulation of a carcass and filleting meat.

A primitive breed of pigs was reared on the territory of Central and Eastern Europe in the middle Ages. Due to the different diets and natural conditions there is a big difference between them, which is primarily reflected in size - in the western part of Central Europe, pigs are larger, while smaller in the eastern part of Central Europe and Eastern Europe. The withers' height of pig is in the range from $52 \mathrm{~cm}$ to $91 \mathrm{~cm}$, with a mean value of 73 cm (Bökönyi 1974: 201, 221-4).

Based on length of one radius, the withers' height of pig was calculated and its value is 77 


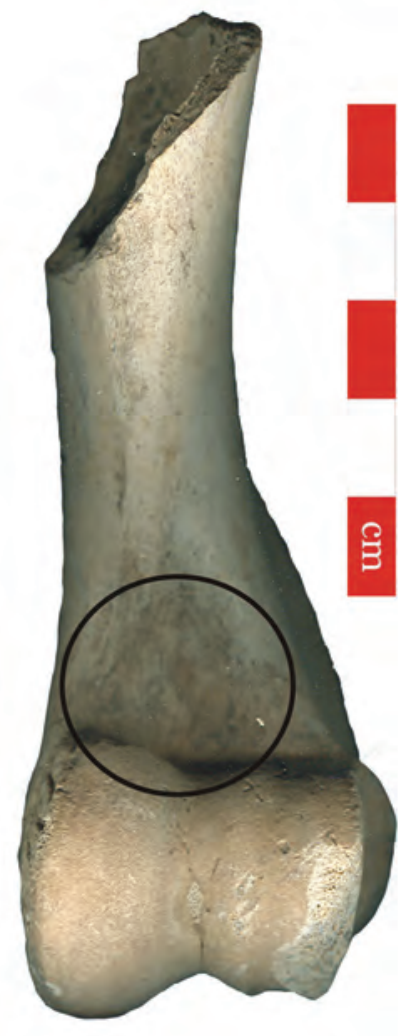

Fig. 5 Left humerus of pig with epigenetic modification missing foramen in fossa olecrani (cranial).

$\mathrm{cm}$. This value is higher than the one from Studenica monastery which is $62.5 \mathrm{~cm}$ (Марковић 2015: 401).

\section{Horse (Equus caballus)}

Equids are represented with two bones - first phalanx and tibia (Fig. 3). It is difficult, on the basis of osteological material, to distinguish horse and mule, primarily because of the great similarity in the skeleton structure of these two species. According to the parameters given by Peters (Peters, 1998) and Johnstone (Johnstone, 2004), horses are represented with one bone - first phalanx, and at least one individual. Exostoses were noticed on volar side of the first phalanx. Since the second specimen, tibia, was fragmented, it could not be attributed to horse or mule with certainty.

The epiphysial fusion shows that, according to the first phalanx, there is one specimen older than $13-15$ months, and, according to the tibia, there is
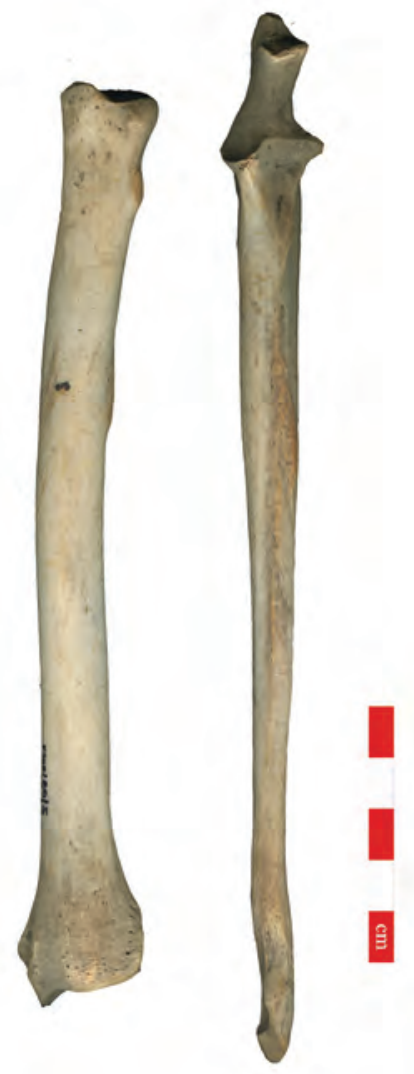

Fig. 6 Left radius and ulna of dog (cranial).

one specimen older than 3-3.5 years (Silver 1969: 285-286).

Although equids were probably used for traction and transport, butchery marks found on caudal side of tibia inflicted by knife during the filleting process, suggest that equid meat was occasionally consumed.

In the beginning of the medieval period heavy cold blood horses became more frequent in the Central Europe (withers' height more than 163 $\mathrm{cm})$. Breeds began to emerge among the light warm blood horses (average withers' height between 147/8 and $163 \mathrm{~cm}$ ) and this process became fully developed at the Late Middle Ages. In medieval Russia, the average withers' height of horses was $132.5 \mathrm{~cm}$, in medieval Latvia was $122.4 \mathrm{~cm}$, and in Central Europe was between 126 and 138 cm (Bökönyi 1974: 292-293).

The first traces of keeping of horses and asses together occurred in West Asia in the first half 
of the second millennium B.C. Therefore, the first mules should be sought there. They were brought to Europe from South-West Asia. The first mule might have appeared in South-East Europe in the $7^{\text {th }}$ century B.C. (Bökönyi 1974: 305-307). During the Roman period mules have had significant role in army, because they were burden animals (Johnstone 2004:72-73). Since mules are more persistent animals than horses, they were used for carrying the burden, draught, agricultural works and riding.

In general, remains of equids are not frequent at medieval archaeological sites in present-day Serbia. Horses are present at sites in Srem - Prosine at Pećinci (2.6\%) and Malo Kuvalovo at Krnješevci (2.63\%) (Блажић 1995: 344), as well as Ras-Gradina site in south-western Serbia (0.71\%) (Блажић 1999a: 34; Blažić 1999b: 441). Since the only one specimen from faunal sample from $\mathrm{Ku}-$ lina-Solotuša site was atributed as a horse $(0.4 \%)$, this value is the closest approximate to one from Ras fortress. Mules are present at Roman sites Felix Romuliana (Dimitrijević and Medović 2007: 315), Viminacium (Vuković 2015: 83) and travel station Mansio Turres (Vuković-Bogdanović i Pejić 2016: 88), and at one medieval Slavic settlement at Pančevo-Livade site in present-day Vojvodina (Младеновић 2015:17). Withers' height could not be determined as the only one long bone present in material is fragmented.

\section{Dog (Canis familiaris)}

Dog is represented by 2 specimens (Fig. 3), and at least one individual is present. Left ulna and left radius belong to the same individual which is at least one year of age (Fig. 6) (Silver 1969: 285). Dog remains are significantly more represented at the sites Malo Kuvalovo at Krnješevci and Prosine at Pećinci in Srem than at Kulina-Solotuša site (Блажић 1995: 343-344).

Dogs were not bred for economic reasons. They were used in hunting, as pets and guards. Before the Roman period, there were only small dog breeds and dogs of medium height, and then a new breeds was introduced, whose number increased significantly since the Middle Ages (Bökönyi 1974: 66, 327).

Apart from species bred for meat production whose bones were often fragmented, dog's long bones have been preserved as whole and they enabled calculation the withers' height which value based on ulna is $55.5 \mathrm{~cm}$ and based on radius is $59.6 \mathrm{~cm}$. Since this is the same individual, this difference is not insignificant and points to some imprecision in calculating dog withers' height based on data given by Harcourt (Harcourt, 1974). According to these values it can be assumed that it was medium-sized dog.

Although dog remains are still a rare find at sites on medieval Serbian states territories, they represent $2.6 \%$ of remains at the site Malo $\mathrm{Ku}$ valovo at Krnješevci and 5\% of faunal remains at the site Prosine at Pećinci (5\%) in Srem (Блажић 1995: 343-344). It can be noticed that already mentioned sites in Srem are richer in dog remains than Kulina-Solotuša site.

\section{Domestic fowl (Gallus domesticus)}

Fowl is represented with 3 bones and at least 1 individual is present (Fig. 3). Left tibia and the left tarsometatarsus belong to the same, adult individual. The third bone, coracoid, also belongs to adult individual.

Domestic fowl was introduced in the Mediterranean area around the $8^{\text {th }}$ century $\mathrm{BC}$, and in central Europe by the $7^{\text {th }}$ century BC (Poole 2010: 156). According to the sources, different domestic fowl types were known across the Roman Empire, since at least the Imperial and Early Byzantine periods - the large domestic fowl was used for fighting and smaller types were kept for their eggs (De Cupere et al. 2005:1587). Due to the high reproduction and easy available source of protein meat and eggs, domestic fowl were the most commonly kept poultry during medieval period.

Apart from Kulina-Solotuša site sample, sparse remains of domestic fowl were also noticed in material from Ras fortress (1.28\%) (Блажић 1999a: 39; Blažić 1999b: 441) and from Gradina-Trešn- 
jevica site (2.7\%) (Булатовић и Марковић 2013: 293). On the other hand, high percentage of fowl remains was recorded in the Studenica monestery, especialy in the sample from the room 1 building $\mathrm{V}(22 \%)$, as well as in sample from area outside of south-eastern monastery wall (19.9\%) (Марковић 2015: 397; Marković, Radišić i Bikić 2016: 102).

\section{GAME}

Among wild animals, the wild boar (Sus scrofa) was the most numerous, represented by four specimens - two maxillae, one atlas and one humerus (Fig. 3). At least two individuals were determined, according to the MNI, based on left maxillae. Based on time of eruption and attrition of teeth, it is assumed that there are two individuals older than 32 months. Butchery marks were found on all specimens and they are inflicted by knives and cleavers during the skinning, disarticulation of a carcass, portioning and filleting meat.

Red deer (Cervus elaphus) is represented by 2 specimens, and at least one adult individual is present (Fig. 3). Left scapula and left ulna carried butchery marks inflicted during the disarticulation of a carcass and filleting meat.

Roe deer (Capreolus capreolus) is also represented by 2 specimens - one scapula and one antler (Fig. 3). At least one individual is determined. Antler indicates the presence of male individual, because only the males grow antlers. Butchery marks were inflicted by cleaver during the cutting off antler (Fig. 7). It is possible that antlers were used for tool production, as indicated by the presence of one specimen with a cut-off points.

Other species were represented only by single specimen: an ulna from brown bear (Ursus arctos) and one scapula from hare (Lepus europaeus) (Fig. 3). Butchery marks were detected on brown bear's ulna and they are inflicted by knife during the skinning. This is not surprising, since bears were mainly hunted for their fur. Butchery marks were also present on hare's scapula and they point

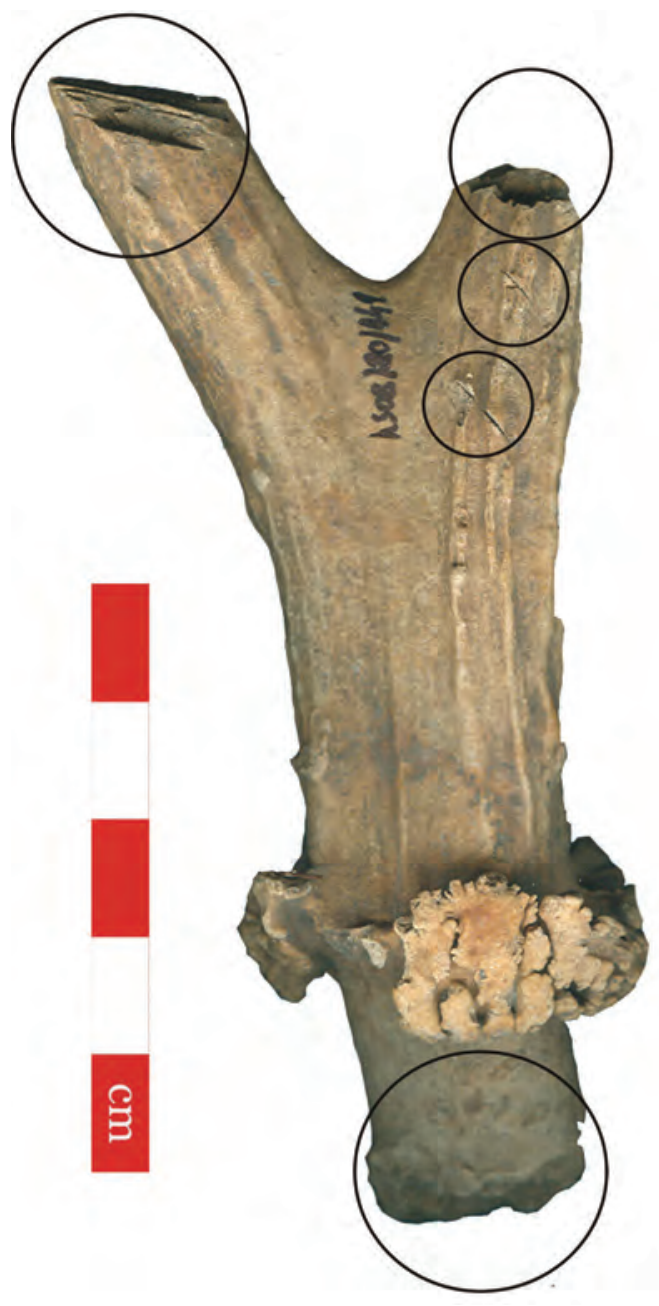

Fig. 7 Left antler of roe deer with butchery marks and modification traces (lateral).

to the process of disarticulation of skeleton.

In general, hunting was of relatively little importance for the inhabitants of the medieval settlements. This is the case with this and with other sites in on medieval Serbian states territories, where the remains of wild species were usually represented with less than 10\% (Блажић 1999a: 32; Blažić 1999b: 440; Булатовић и Марковић 2013: 293; Марковић 2015: 397). A bit higher percentage of wild species were noticed at the sites in Srem: Malo Kuvalovo at Krnješevci 16\%, Prosine site at Pećinci 10\%, and Žirovac at Ruma 35.5\% (Блажић 1995:343). 


\section{CONCLUSION}

This paper presents the results of archaeozoological analysis of faunal material from fortified castle at the Kulina-Solotuša site. Animal remains were collected from squares B1-B6 (chamber B with a cistern), B7-B9 (the eastern wall of the fortress and tower in the south-eastern corner) and V1 (eastern entrance to the fortified castle) (Fig. 2). This area was probably used as a waste disposal from which the analysed faunal remains come from. It is still not clear why this part of the castle was used for that purpose. Presence of faunal remains at this place might suggest that the inhabitants of the castle were not able to dispose waste outside of castle because of the possible siege. Faunal sample is small, but considering the fact that archaeozoological publications of contemporaneous sites in Serbia are not numerous, it was used to provide informations about relationships between people and animals, dietary strategies, and uses of the animals in medieval Serbian states.

The age of animals, fragmentation and the presence of a large number of butchery traces indicate that most of the animal bones from Kulina-Solotuša site are remains of food. Quite few dog bones represent most probably remains of pets kept in castle.

Domestic animals had the most important role in the economy of the site. Based on the Number of Identified Specimens (NISP), the most frequent among them were cattle, sheep and goats, and pig, while remains of horse, dog and domestic fowl were rare (Fig. 3).

Faunal composition and animal exploitation pattern are consistent with other medieval sites. Differences are notable in frequency of distribution of different taxa. Percentage ratio between the economicaly most important domestic species at Kulina-Solotuša site differ from those of the material from the other sites in medieval Serbian state - Ras fortress (Блажић 1999a: 32; Blažić 1999b: 440), Gradina-Trešnjevica fortress (Булатовић и Марковић 2013: 293), and Studenica mon- estery (Марковић 2015: 397). Namely, the most frequent species among remains from these sites are sheep and goats, while cattle remains are the most frequent at Kuilina-Solotuša site. Cattle are, also, the most frequent species at the lowland sites in Srem - Malo Kuvalovo at Krnješevci, Žirovac at Ruma and Prosine at Pećinci (Блажић 1995:343). This is an interesting observation because Kulina-Solotuša site has more similar geographical position to Ras and GradinaTrešnjevica fortresses.

During the medieval period small local domestic breeds were kept across the Europe. Metric analysis has shown that domestic animals from castle at Kulina-Solotuša site were relatively common for that period concerning size and growth.

Among the hunted species were wild boar, red deer, roe deer, brown bear and hare. According to the NISP and MNI, wild boar is the most numerous wild species. Since the sample is small, it can only be assumed which was the most important hunting species at the Kulina-Solotuša site (Fig. 3). At the other medieval sites in Serbia, the most hunted species was the red deer (Блажић 1995:343, Блажић 1999a: 32; Blažić 1999b: 440; Булатовић и Марковић 2013: 293), and in the case of monastery Studenica, hare (Марковић 2015: 397). Based on a small number of game remains, it can be assumed that mostly adult individuals have been hunted.

Although the sample is small, the results provide basic information on animal husbandry, hunting and diet strategy of the inhabitants of castle at the Kulina-Solotuša site. Archaeozoological analysis of the faunal remains from the other parts of the castle are in progress and it will complete the data obtained in this analysis. 


\section{BIBLIOGRAPHY}

\section{Блажић, С. 1995}

Остаци животињских врста са локалитета на траси ауто-пута кроз Срем, у: Археолошка истраживаға дуж ауто-пута кроз Срем, 3. Вапа (ур.), Нови Сад: Покрајински завод за заштиту споменика културе, 331-346.

\section{Блажић, С. 1999а}

Остаци животињских костију са локалитета Рас-Градина, Новопазарски зборник 23, 29-54.

\section{Blažić, S. 1999b}

Ostaci životinjskih kostiju sa lokaliteta RasGradina, u: Tvrđava Ras, M. Popović (ur.), Beograd: Arheološki institut: 439-445.

\section{Boessneck, J. 1969}

Osteological Differences between Sheep (Ovis aries Linn.) and Goat (Capra hircus Linn.), in: Science in Archaeology: a survey of progress and research, D. Brothwell and E. Higgs (eds.), London: Thames and Hudson: 331-358.

Boyd, J. S. et al. 1994

Colour Atlas of Clinical Anatomy of the Dog and Cat, London: Mosby-Wolfe.

Bökönyi, S. 1974

History of Domestic Mammals in Central and Eastern Europe, Budapest: Academiai Kiado.

\section{Budras, K. D. at al. 2009}

Anatomy of the horse, Hannover: Schlütersche Verlagsgesellschaft.

\section{Булатовић Ј. и Марковић Н. 2013}

Остаци животиња из средњовековног утврђења Градина-Трешњевица код Ивањице, Зборник Народног музеја, Београд, XXI/1: 291298.

\section{Цалкин, В. И. 1956}

Материалы для истории скотоводства и охоты в Древней Руси, МИА 51, Москва.

\section{Cohen, A. and Serjeantson, D. 1996}

A manual for the identification of bird bones from archaeological sites ( $2^{\text {nd }}$ edn.), London: Birkbeck College.

\section{Davis, S. J. M. 1987}

The Archaeology of animals, London: Routledge.

\section{De Cupere, B. et al. 2005}

Ancient breeds of domestic fowl (Gallus gallus $\mathrm{f}$. domestica) distinguished on the basis of traditional observations combined with mixture analysis, Journal of Archaeological Science 32: 1587-1597.

Дероко, А. 1950

Средњовековни градови у Србији, Црној Гори и Македонији, Београд: Просвета.

\section{Dimitrijević, V. and Medović, A. 2007}

Animal and plant remains in a tomb in test-pit $1 / 05$, outside the fortified Imperial palace Felix Romuliana, Старинар LVII: 315-323.

\section{Driesh, A. 1976}

A guide to the measurement of animal bones from archaeological sites, Cambridge Mass.: Peabody Museum at Harvard University.

Frandson, R., Lee Willke, W. and Dee Fails, A. 2009

Anatomy and Physiology of Farm Animals (7th edition), Ames: Wiley-Blackwell.

Halstead, P., Collins, P. and Isaakidou V. 2002 Sorting the Sheep from the Goats: Morphological Distinctions between the Mandibles and Mandibular Teeth of Adult Ovis and Capra, Journal of Archaeological Science 29: 545-553. 


\section{Harcourt R. 1974}

The dog in prehistoric and early historic Britain, Journal of Archaeological Science 1, Amsterdam: 151-175.

\section{Hilson, S. 2005}

Teeth (Second edition), Cambridge: University Press.

\section{Јанковић, Ђ. и Праштало, П. 2007}

Извештај о археолошким истраживањима локалитета Кулина-Солотуша за 2007. годину.

\section{Johnstone, C. J. 2004}

A Biometric Study of Equids in the Roman World, Thesis submitted for PhD, University of York, Departement of Archaeology.

\section{Kubasiewicz, M. i Gawlikowski, J. 1965}

Szczątki zwierzęce $\mathrm{z}$ wczesnośredniowiecznego grodu w Kołobrzegu, Wydział Nauk Przyrodniczo-Rolniczych XXIV, Szczecin.

\section{Matolcsi, J. 1970}

Historische Erforschunge der Körpergrösse des Rindes auf Grund von ungarischen Knochenmaterial, Zeitschr. f. Tieryuchtg. u Zuchgsbiol. 87, 2: 89-137.

\section{Марковић, Н. 2015}

Исхрана у манастиру Студеници: археозоолошка сведочанства, у: Манастир Студенииа: археолошка открића, М. Поповић (ур.), Београд: Археолошки институт, 291-298.

\section{Marković, N., Radišić, T. i Bikić, V. 2016}

Uloga živine u srednjovekovnoj ekonomiji manastira Studenica, u: Bioarheologija na Balkanu: Metodološke, komparativne $i$ rekonstruktivne studije života u prošlosti, $\mathrm{N}$. Miladinović-Radmilović i S. Vitezović (ur.), Beograd - Sremska Mitrovica: Srpsko arheološko društvo i Blago Sirmijuma: 99-116.

\section{Младеновић, Т. 2015}

Значај животиґа у економији насеља из 7-13. века на локалитету Панчево-Ливаде (јужни Банат), Мастер рад, Филозофски факултет, Универзитет у Београду.

\section{Peters, J. 1998}

Römische Tierhaltung und Tierzucht: eine Synthese aus archäozoologischer Untersuchung und schriftlich-bildlicher Überlieferung. Rahden/ Westfalen: Leidorf.

\section{Петковић, С. 1982}

Пећка Патријариија, Београд: Српска Патријаршија.

\section{Poole, K. 2010}

Bird Introductions, in: Extinctions and Invasions: A Social History of British Fauna, T. O'Connor and N. Sykes (eds.), Oxford: Windgather: 156166.

\section{Prummel, W. and Frisch H. 1986}

A guide for the distinction of species, sex and body side in bones of sheep and goats, Journal of Archaeological Science 13: 567-577.

\section{Prummel, W. 1988}

Distinguishing features of postcranial skeletal elements of cattle, Bos primigenius f. taurus, and red deer, Cervus elaphus, Schriften aus der Archaologisch - Zoologischen Arbeitsgruppe SchleswigKiel 12: 1-52.

\section{Reitz, E. J. and Wing, E. S. 2008}

Zooarchaeology (2nd Edition), Cambridge: Cambridge University Press.

\section{Schmid, E. 1972}

Atlas of Animal Bones: for prehistorians, archaeologists and quaternary geologists, New York: Elsevier. 
Schramm, Z. 1967

Long bones and heights in withers of goat, Roczniki Wyzszej Szkoly Rolniczej w Poznaniu 36, Poznan: 89-105.

\section{Silver, I. A. 1969}

The ageing of domestic animals, in: Science in Archaeology: a survey of progress and research, D. Brothwell and E. Higgs (eds.), London: Thames and Hudson: 283-302.

\section{Teichert, M. 1975}

Osteometrische Untersuchungen zur Berechnung der Widerristhöhe bei Schafen, In: Archaeozoological studies, A.T. Clason (ed.), Amsterdam-Oxford-New York: 51-69.

\section{Théodoridès, J. 1964}

Intérêt pour l'histoire de la zoologie de certaines fresques médiévales Serbes, in: Actes du XIIe congrès international d'études Byzantines III, Beograd: Comité Yougoslave des études Byzantines: 385-388.

\section{Vuković, S. 2015}

Životinje u rimskim amfiteatrima. Studija slučaja amfiteatra u Viminacijumu, Doktorska disertacija, Filozofski fakultet, Univerzitet u Beogradu.

Vuković-Bogdanović, S. i Pejić, P. 2016

Konji, magarci i mule iz rimske putne stanice Mansio Turres, Архаика 4, 85-103.

Zeder, M. and Lapham, H. 2010

Assessing the reliability of criteria used to identify postcranial bones in sheep, Ovis, and goats, Capra, Journal of Archaeological Science 37: 2887-2905.

\section{Zeder, M. and Pilaar, S. 2010}

Assessing the reliability of criteria used to identify mandibles and mandibular teeth in sheep, Ovis, and goats, Capra, Journal of Archaeological Science 37: 225-242.

\section{REZIME \\ OSTACI ŽIVOTINJA \\ IZ UTVRĐENOG \\ SREDNJOVEKOVNOG ZAMKA NA LOKALITETU KULINA- SOLOTUŠA}

\section{KLJUČNE REČI: OSTACI ŽIVOTINJA, SREDN- JOVEKOVNI ZAMAK, SOLOTUŠA, STOČARST- VO, LOV, STRATEGIJA ISHRANE.}

Materijal koji je analiziran u ovom radu potiče iz utvrđenog zamka na lokalitetu Kulina-Solotuša, koji je u 15. veku podignut na planini Tari (Sl. 1). Uzorak faune ručno je sakupljen tokom arheoloških istraživanja 2008. godine u kvadratima B1-B6 (prostorija B sa cisternom), B7-B9 (prostor uz istočni zid utvrđenja i kula u jugoistočnom uglu) i V1 (istočni ulaz u zamak) (Sl. 2). Ovaj prostor je u jednom trenutku korišćen za odlaganje otpada. Razlozi za to su, za sada, nepoznati, ali je moguće da usled opsade zamka stanovnici nisu bili u mogućnosti da otpad odlazu van njega. Uzorak je mali ali je usled malobrojnih arheozooloških publikacija o uzorcima sa istovremenih lokalieta u Srbiji iskorišćen kako bi se dobili podaci o odnosu ljudi i životinja, načinu ishrane i eksploatacije životinja i njihovih produkata u srpskim srednjovekovnim zemljama.

Arheozoološka analiza faunističkog materijala je pokazala da on predstavlja, uglavnom, ostatke hrane i da se može svrstati u kategoriju stambenog otpada ovog zamka. Stepen fragmentacije je jako visok $-89 \%$, dok je očuvanost kostiju i zuba relativno dobra. Tragovi površinskog raspadanja kosti zabeleženi su na $35.4 \%$ ukupnog broja određenih primeraka, dok se tragovi gorenja javljaju na samo $0.8 \%$ primeraka. Kosti na kojima se nalaze tragovi glodanja, uglavnom pasa, čine 33.3\% materijala.

Uzorak faune sadrži 559 fragmenata, od kojih je do roda i vrste određeno njih 246. Kosti domaćih životinja (96\%) znatno su zastupljenije od divljih (4\%). Ovakav odnos nije neuobičajen za ovaj period, budući da je situacija slična i na 
ostalim srednjovekovnim lokalitetima u Srbiji (Блажић 1995; Блажић 1999a; Blažić 1999b; Булатовић и Марковић 2013; Марковић 2016).

U materijalu su prisutne sledeće domaće vrste - goveče (Bos taurus), ovca (Ovis aries), koza (Capra hircus), svinja (Sus domesticus), konj (Equus caballus), pas (Canis familiaris), domaća kokoš (Gallus domesticus), kao i sledeće divlje vrste - divlja svinja (Sus scrofa), jelen (Cervus j elaphus), srndać (Capreolus capreolus), mrki medved (Ursus arctos) i zec (Lepus europaeus). Usled visokog stepena fragmentacije, neke primerci određeni su do klase i svrstani su u kategoriju krupnih i srednje krupnih sisara (Tabela 1).

Strategija ishrane stanovnika ovog utvrđenja bila je zasnovana na uzgoju domaćih životinja. Najviše je gajeno goveče $(46.3 \%)$, zatim ovce i koze (38.6\%) i svinje (8.1\%) (Sl. 3). Ove vrste su ujedno bile i glavni izvor hrane. Gajenje goveda, ovaca i koza bilo je usmereno na eksploataciju sekundarnih proizvoda - mleka i vune (Sl. 4). Pored toga, goveda su verovatno korišćena i za vuču. Podaci o starosti svinja pokazuju da su u ishrani uglavnom kotišćene životinje između jedne i tri godine starosti (Sl. 4). Prisustvo adultnih jedinki ukazuje na to da su neke jedinke gajene duže zbog reprodukcije. U ishrani je korišćeno i meso ekvida, na šta ukazuju tragovi filetiranja na jednoj tibiji. Ostaci ptica su malobrojni ali ukazuju na to da su stanovnici ovog zamka mogli koristiti i meso i jaja domaće kokoši.

Lov nije imao značajno mesto u ekonomiji. Najzastupljenija divlja vrsta je divlja svinja (Sl. 3). Na osnovu prisutnih primeraka može se zaključiti da je lov bio orijentisan prema odraslim jedinkama, na čijim su kostima zabeleženi i tragovi dranja, dezartikulacije skeleta i filetiranja. U ishrani je korišćeno i meso srndaća i jelena, na čijim su kostima, takođe, primećeni tragovi dezartikulacije skeleta i filetiranja. Moguće je da su rogovi srndaća korišćeni za izradu predmeta na šta ukazuje prisustvo jednog roga sa odsečenim parošcima (Sl. 7). Zec je, takođe, korišćen u ishrani, ali je verovatno lovljen i zbog krzna. U materijalu je prisutna i jedna kost mrkog medveda, na kojoj su primećeni tragovi dranja, odnosno, uklanjaja krzna.

Tragovi kasapljenja zabeleženi su na 52\% primeraka. Nastali su tokom dranja, dezartikulacije skeleta, filetiranja i komadanja mesa, korišćenjem različitih noževa i satara.

Iako je uzorak mali, ovim istraživanjem dobijeni su preliminarni podaci o stočarstvu, lovu i ishrani stanovnika zamka na lokalitetu Kulina-Solotuša. Analiza faunističkog materijala koji potiče iz ostalih delova zamka je u toku i ona će upotpuniti podatke dobijene ovom analizom. 


\section{APPENDIX}

Bone measurements according to the standardized system of A. von den Driesch (1976)

Mere kostiju po standardizovanom sistemu A. fon den Driš (1976), prilagođeno

\begin{tabular}{|c|c|}
\hline Meas. 1 & Length: Gonion caudale - aboral border of the alveolus of $\mathrm{M}_{3}$ \\
\hline Meas. 2 & Length: Gonion caudale - oral border of the alveolus of $\mathrm{P}_{2}$ \\
\hline Meas. 3 & Length: Gonion caudale - the most aboral indentation of the mental foramen \\
\hline Meas. 4 & $\begin{array}{l}\text { Aboral height of the vertical ramus: Gonion ventrale - highest point of the con- } \\
\text { dyle process }\end{array}$ \\
\hline Meas. 5 & $\begin{array}{l}\text { Middle height of the vertical ramus: Gonion ventrale - deepest point of the man- } \\
\text { dibular notch }\end{array}$ \\
\hline Meas. 6 & Oral height of the vertical ramus: Gonion ventrale - Coronion \\
\hline Meas. 7 & Length \\
\hline Meas. 8 & Greatest (oro-aboral) diameter of the horncore base \\
\hline Meas. 9 & Least (latero-medial) diameter of the horncore base \\
\hline Meas. 10 & Distal circumference of the burr \\
\hline $\mathrm{L}$ & Length \\
\hline B & Breadth \\
\hline GL & Greatest length \\
\hline GB & Greatest breadth \\
\hline $\mathrm{H}\left(\mathrm{D}_{2}, \mathrm{P}_{2}, \mathrm{M}_{1}\right)$ & Height of the mandible in front of $\mathrm{D}_{2}, \mathrm{P}_{2}$ or $\mathrm{M}_{1}$ \\
\hline $\mathrm{H}\left(\mathrm{M}_{3}\right)$ & Height of the mandible behind $\mathrm{M}_{3}$ \\
\hline BFcr & Greatest breadth of the Facies articularis cranialis \\
\hline SVB & Smallest breadth of the vertebra \\
\hline SLC & Smallest length of the Collum scapulae \\
\hline GLP & Greatest length of the Processus articularis \\
\hline LG & Length of the glenoid cavity \\
\hline BG & Breadth of the glenoid cavity \\
\hline Bp & Greatest breadth of the proximal end \\
\hline $\mathrm{Dp}$ & Depth of the proximal end \\
\hline SD & Smallest breadth of the diaphysis \\
\hline
\end{tabular}




\begin{tabular}{|c|c|}
\hline $\mathrm{Bd}$ & Greatest breadth of the distal end \\
\hline Dd & Depth of the distal end \\
\hline $\mathrm{BT}$ & Greatest breadth of the trochlea \\
\hline DPA & Depth across the processus anconaeus \\
\hline SDO & Smallest depth of the olecranon \\
\hline BPC & Greatest breadth across the coronoid process \\
\hline BFp & Greatest breadth of the Facies articularis proximalis \\
\hline BFd & Greatest breadth of the Facies articularis distalis \\
\hline LA & Length of the acetabulum including the lip \\
\hline LAR & Length of the acetabulum of the rim \\
\hline SB & Smallest breadth of the shaft of ilium \\
\hline GLl & Greatest length of the lateral half \\
\hline GLm & Greatest length of the medial half \\
\hline $\mathrm{Dl}$ & Greatest depth of the lateral half \\
\hline $\mathrm{Dm}$ & Greatest depth of the medial half \\
\hline GLpe & Greatest length of the peripheral (abaxial) half \\
\hline DLS & Greatest diagonal length of the sole \\
\hline MBS & Middle breadth of the sole \\
\hline Ld & Length of the dorsal surface \\
\hline $\mathrm{Lm}$ & Medial length \\
\hline $\mathrm{BF}$ & Breadth of the Facies articularis basalis \\
\hline $\mathrm{La}$ & $\begin{array}{l}\text { Axial length: from the Tuberculum centrale to the distal border of the Trochlea } \\
\text { tibiotarsi }\end{array}$ \\
\hline Dip & $\begin{array}{l}\text { Greatest diagonal of the proximal end: from the Condylus medialis femoralis to } \\
\text { the Crista lateralis }\end{array}$ \\
\hline
\end{tabular}




\section{Bos taurus}

\begin{tabular}{|c|c|c|}
\hline \multicolumn{3}{|c|}{ Scapula } \\
\hline SLC & 52.8 & 42.5 \\
\hline GLP & 61.6 & 51.8 \\
\hline LG & 53.6 & 48.9 \\
\hline BG & 44.1 & 38.3 \\
\hline
\end{tabular}

\begin{tabular}{|c|c|c|c|c|c|}
\hline \multicolumn{7}{|c|}{ Mandibula } \\
\hline $\mathrm{P}_{2}-\mathrm{P}_{4}$ & $/$ & $/$ & 47.5 & 0 & 54.7 \\
\hline $\mathrm{H}\left(\mathrm{P}_{2}\right)$ & $/$ & 30.7 & 29.5 & 24.4 & 29.1 \\
\hline $\mathrm{H}\left(\mathrm{M}_{1}\right)$ & $/$ & $/$ & 47.2 & $/$ & 41.4 \\
\hline $\mathrm{M}_{1}-\mathrm{M}_{3}$ & $/$ & $/$ & $/$ & $/$ & 84.1 \\
\hline $\mathrm{L} \mathrm{M}_{3}$ & 31.2 & $/$ & $/$ & 31.7 & 36.6 \\
\hline $\mathrm{B}_{3}$ & 12.7 & $/$ & $/$ & 14.7 & 12.8 \\
\hline $\left.\mathrm{H}_{(\mathrm{M}}\right)$ & $/$ & $/$ & $/$ & 62.7 & 68.5 \\
\hline $\mathrm{P}_{2}-\mathrm{M}_{3}$ & $/$ & $/$ & $/$ & $/$ & 138.9 \\
\hline Meas. 1 & $/$ & $/$ & $/$ & $/$ & 99.7 \\
\hline Meas. 2 & $/$ & $/$ & $/$ & $/$ & 236.9 \\
\hline Meas. 3 & $/$ & $/$ & $/$ & $/$ & 300.1 \\
\hline Meas. 4 & $/$ & $/$ & $/$ & $/$ & 136.5 \\
\hline Meas. 5 & $/$ & $/$ & $/$ & $/$ & 142.2 \\
\hline Meas. 6 & $/$ & $/$ & $/$ & $/$ & 193.5 \\
\hline
\end{tabular}

\begin{tabular}{|c|c|c|}
\hline \multicolumn{3}{|c|}{ Radius+Ulna } \\
\hline Bd & 60.2 & 52.9 \\
\hline Dd & 49.4 & $/$ \\
\hline BFd & 44.9 & 48.2 \\
\hline
\end{tabular}




\begin{tabular}{|c|c|c|c|c|c|c|c|}
\hline \multicolumn{10}{|c|}{ Radius } \\
\hline $\mathrm{Bp}$ & $/$ & 61.5 & 62.4 & 63.6 & 72 & 63.5 & 63.4 \\
\hline $\mathrm{BFp}$ & $/$ & 56.3 & 56.8 & 58.1 & 67.1 & 60.4 & 60.5 \\
\hline $\mathrm{Bd}$ & 63.7 & $/$ & $/$ & $/$ & $/$ & $/$ & $/$ \\
\hline $\mathrm{BFd}$ & 51.5 & $/$ & $/$ & $/$ & $/$ & $/$ & $/$ \\
\hline
\end{tabular}

\begin{tabular}{|c|c|c|c|c|c|c|}
\hline \multicolumn{7}{|c|}{ Ulna } \\
\hline DPA & 45.2 & 47.7 & $/$ & 49.7 & $/$ & $/$ \\
\hline SDO & $/$ & 40.1 & $/$ & $/$ & $/$ & $/$ \\
\hline BPC & 32.2 & 36.2 & 38.1 & 38.4 & 35.7 & 35.9 \\
\hline
\end{tabular}

\begin{tabular}{|c|c|}
\hline \multicolumn{2}{|c|}{ Pelvis } \\
\hline LA & 61.9 \\
\hline LAR & 49.9 \\
\hline
\end{tabular}

\begin{tabular}{|c|c|}
\hline \multicolumn{2}{|c|}{ Sacrum } \\
\hline HFcr & 24.8 \\
\hline
\end{tabular}

\begin{tabular}{|c|c|}
\hline \multicolumn{2}{|c|}{ Patella } \\
\hline GB & 37.4 \\
\hline
\end{tabular}

\begin{tabular}{|c|c|c|c|c|c|c|c|c|c|c|c|}
\hline \multicolumn{10}{|c|}{ Tibia } \\
\hline Bp & $/$ & $/$ & $/$ & $/$ & 69.8 & $/$ & 88.2 & $/$ & $/$ & $/$ & $/$ \\
\hline $\mathrm{SD}$ & $/$ & $/$ & $/$ & $/$ & $/$ & 30.9 & $/$ & $/$ & $/$ & $/$ & $/$ \\
\hline $\mathrm{Bd}$ & 58.7 & 56.1 & 52.8 & 48.5 & $/$ & 54.8 & $/$ & 54.3 & 56.3 & 54.9 & 50.3 \\
\hline $\mathrm{Dd}$ & 39.7 & 38.7 & $/$ & 35.1 & $/$ & 39.8 & $/$ & 42.3 & 42.6 & 44.3 & 38.8 \\
\hline
\end{tabular}




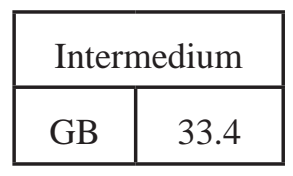

\begin{tabular}{|c|c|}
\hline \multicolumn{2}{|c|}{ Carpale 2+3 } \\
\hline $\mathrm{GB}$ & 40.2 \\
\hline
\end{tabular}

\begin{tabular}{|c|c|c|}
\hline \multicolumn{3}{|c|}{ Os centrotarsale } \\
\hline GB & 49.2 & 52.7 \\
\hline
\end{tabular}

\begin{tabular}{|c|c|}
\hline \multicolumn{2}{|c|}{ Carpale 4+5 } \\
\hline GB & 22.9 \\
\hline
\end{tabular}

\begin{tabular}{|c|c|c|c|c|c|c|c|}
\hline \multicolumn{7}{|c|}{ Calcaneus } \\
\hline GL & 112.7 & $/$ & 115.9 & $/$ & $/$ & 114.3 & $/$ \\
\hline GB & 35.8 & 38.1 & 39.1 & 41.6 & 37.5 & 37.9 & 31.2 \\
\hline
\end{tabular}

\begin{tabular}{|c|c|c|c|c|c|c|c|}
\hline \multicolumn{7}{|c|}{ Astragalus } \\
\hline GLl & 61.5 & 55.6 & 63.8 & 59.4 & 58.2 & 52.1 & 51.7 \\
\hline GLm & 52.8 & $/$ & 57.5 & 52.8 & 54.5 & 48.4 & 48.1 \\
\hline DL & 31.7 & 32.1 & 36.9 & 31.8 & 35.3 & 29.3 & 28.9 \\
\hline DM & 32.8 & 33.7 & 30.8 & $/$ & 31.8 & $/$ & 24.7 \\
\hline BD & 38.3 & $/$ & 41.1 & 36.4 & 37.9 & 34.9 & 32.3 \\
\hline
\end{tabular}

\begin{tabular}{|c|c|c|c|c|c|c|c|c|c|c|c|c|}
\hline \multicolumn{10}{|c|}{ Metacarpus } \\
\hline Bp & 49.7 & 50.6 & 51.1 & $/$ & 48.1 & 46.6 & 47.1 & 46.9 & 47 & $/$ & 47.7 & 46.3 \\
\hline Dp & 29.2 & 30.1 & 30.9 & $/$ & 29.3 & 29.1 & 28.4 & 27.9 & 25.7 & $/$ & 30.1 & 25.3 \\
\hline SD & 25.9 & $/$ & $/$ & $/$ & 27.4 & $/$ & 24.8 & $/$ & 21.9 & $/$ & 24.4 & 24.7 \\
\hline Bd & $/$ & $/$ & $/$ & 55.2 & $/$ & $/$ & $/$ & $/$ & $/$ & 49.1 & $/$ & $/$ \\
\hline Dd & $/$ & $/$ & $/$ & 28.8 & $/$ & $/$ & $/$ & $/$ & $/$ & 27.3 & $/$ & $/$ \\
\hline
\end{tabular}




\begin{tabular}{|c|c|c|c|c|c|c|c|}
\hline \multicolumn{7}{|c|}{ Metatarsus } \\
\hline GL & $/$ & 148.3 & $/$ & $/$ & $/$ & $/$ & $/$ \\
\hline Bp & 43.6 & 33.1 & 39.3 & 37.6 & 38.8 & 33.2 & 37.8 \\
\hline Dp & $/$ & 34.6 & 38.9 & 36.2 & 39.4 & 30.8 & 37.3 \\
\hline SD & $/$ & 18.3 & $/$ & $/$ & $/$ & 18.5 & $/$ \\
\hline Bd & $/$ & 41.6 & $/$ & $/$ & $/$ & $/$ & $/$ \\
\hline Dd & $/$ & 24.1 & $/$ & $/$ & $/$ & $/$ & $/$ \\
\hline Withers' height (cm) & $/$ & 78.3 & $/$ & $/$ & $/$ & $/$ & $/$ \\
\hline
\end{tabular}

\begin{tabular}{|c|c|c|c|c|c|c|}
\hline \multicolumn{7}{|c|}{ Phalanx I } \\
\hline GLpe & $/$ & 54.9 & 49.5 & $/$ & 51.5 & 51.6 \\
\hline Bp & 30.6 & $/$ & $/$ & $/$ & 25.6 & 25.2 \\
\hline Dp & 33.2 & $/$ & $/$ & $/$ & $/$ & $/$ \\
\hline SD & 26.1 & 26.9 & 21.9 & $/$ & 19.1 & 21.7 \\
\hline Bd & $/$ & $/$ & $/$ & 24.1 & 24.9 & 22.1 \\
\hline
\end{tabular}

\begin{tabular}{|c|c|}
\hline \multicolumn{2}{|c|}{ Phalanx II } \\
\hline GL & 32.3 \\
\hline GLpe & 32.7 \\
\hline Bp & 21.6 \\
\hline Dp & 24.5 \\
\hline SD & 19.1 \\
\hline Bd & 17.8 \\
\hline Dd & 20.8 \\
\hline
\end{tabular}

\begin{tabular}{|c|c|c|c|}
\hline \multicolumn{4}{|c|}{ Phalanx III } \\
\hline DLS & 55.7 & 57.4 & 49.9 \\
\hline Ld & 15.4 & 18.1 & 41.2 \\
\hline MBS & 44.7 & $/$ & 16.5 \\
\hline
\end{tabular}


Ovis aries

\begin{tabular}{|c|c|c|c|}
\hline \multicolumn{4}{|c|}{ Horn core } \\
\hline Meas. 7 & 116.2 & $/$ & $/$ \\
\hline Meas. 8 & 37.9 & 25.4 & 23.3 \\
\hline Meas. 9 & 25.6 & 16.2 & 15.7 \\
\hline
\end{tabular}

\begin{tabular}{|c|c|c|c|c|c|}
\hline \multicolumn{7}{|c|}{ Mandibula } \\
\hline $\mathrm{D}_{2}-\mathrm{D}_{4}$ & $/$ & $/$ & 30.1 & $/$ & 30.9 \\
\hline $\mathrm{H}\left(\mathrm{D}_{2}\right)$ & $/$ & $/$ & 11.5 & 10.3 & 12.4 \\
\hline $\mathrm{L} \mathrm{D}_{4}$ & $/$ & $/$ & 17.2 & $/$ & 17.6 \\
\hline $\mathrm{B}_{4}$ & $/$ & $/$ & 4.9 & $/$ & 5.1 \\
\hline $\mathrm{P}_{2}-\mathrm{P}_{4}$ & 21.1 & 22.5 & $/$ & $/$ & $/$ \\
\hline $\mathrm{H}\left(\mathrm{P}_{2}\right)$ & 15.4 & 15.2 & $/$ & $/$ & $/$ \\
\hline $\mathrm{H}\left(\mathrm{M}_{1}\right)$ & $/$ & $/$ & $/$ & $/$ & 21.1 \\
\hline
\end{tabular}

\begin{tabular}{|c|c|}
\hline \multicolumn{2}{|c|}{ Maxilla } \\
\hline $\mathrm{P}^{2}-\mathrm{P}^{4}$ & 24.7 \\
\hline L praemaxillae & 67.3 \\
\hline
\end{tabular}

\begin{tabular}{|c|c|}
\hline \multicolumn{2}{|c|}{$\mathrm{M}_{3}$} \\
\hline $\mathrm{L}$ & 19.7 \\
\hline $\mathrm{B}$ & 6.9 \\
\hline
\end{tabular}

\begin{tabular}{|c|c|}
\hline \multicolumn{2}{|c|}{ Axis } \\
\hline BFcr & 17.9 \\
\hline SVB & 24.3 \\
\hline
\end{tabular}




\begin{tabular}{|c|c|c|c|c|c|c|c|}
\hline \multicolumn{7}{|c|}{ Scapula } \\
\hline SLC & 21.9 & 21.3 & 19.9 & 20.8 & 19.6 & 21.8 & 18.6 \\
\hline GLP & $/$ & $/$ & 34.4 & $/$ & 34.7 & 31.8 & 32.6 \\
\hline LG & $/$ & 24.9 & 26.7 & $/$ & 26.4 & 25.3 & 21.4 \\
\hline BG & $/$ & $/$ & 21.3 & $/$ & 23.5 & 19.3 & 20.3 \\
\hline
\end{tabular}

\begin{tabular}{|c|c|c|c|}
\hline \multicolumn{4}{|c|}{ Humerus } \\
\hline Bd & 29.9 & 29.6 & 29.5 \\
\hline Dd & 24.3 & $/$ & 23.7 \\
\hline BT & 30.6 & 28.3 & 28.4 \\
\hline
\end{tabular}

\begin{tabular}{|c|c|c|c|c|c|}
\hline \multicolumn{7}{|c|}{ Radius } \\
\hline GL & $/$ & $/$ & 149.5 & 163.9 & $/$ \\
\hline Bp & $/$ & $/$ & 33.1 & 32.2 & 27.5 \\
\hline BFp & $/$ & $/$ & 29.1 & 30.1 & 25.8 \\
\hline Dp & $/$ & $/$ & 26.4 & 15.9 & $/$ \\
\hline SD & $/$ & $/$ & 15.4 & 16.3 & $/$ \\
\hline Bd & 28.1 & 34.8 & 28.3 & 29.6 & $/$ \\
\hline BFd & 24.2 & $/$ & 20.4 & 25.7 & $/$ \\
\hline Dd & $/$ & 22.7 & 22.5 & 20.2 & $/$ \\
\hline Withers' height (cm) & $/$ & $/$ & 59.8 & 65.6 & $/$ \\
\hline
\end{tabular}

\begin{tabular}{|c|c|}
\hline \multicolumn{2}{|c|}{ Ulna } \\
\hline DPA & 25.9 \\
\hline SDO & 21.2 \\
\hline BPC & 19.6 \\
\hline
\end{tabular}




\begin{tabular}{|c|c|c|}
\hline \multicolumn{3}{|c|}{ Pelvis } \\
\hline SB & 9.8 & $/$ \\
\hline LA & 27.2 & 26.5 \\
\hline LAR & $/$ & 23.2 \\
\hline
\end{tabular}

\begin{tabular}{|c|c|c|}
\hline \multicolumn{3}{|c|}{ Femur } \\
\hline $\mathrm{Bp}$ & $/$ & 44.3 \\
\hline $\mathrm{SD}$ & $/$ & 21.7 \\
\hline $\mathrm{Bd}$ & 38.2 & $/$ \\
\hline $\mathrm{Dd}$ & 45.1 & $/$ \\
\hline
\end{tabular}

\begin{tabular}{|c|c|c|c|c|c|c|c|c|c|c|c|}
\hline \multicolumn{10}{|c|}{ Tibia } \\
\hline Bp & $/$ & 41.3 & $/$ & $/$ & 43.6 & $/$ & $/$ & $/$ & $/$ & $/$ & $/$ \\
\hline Dp & $/$ & 39.8 & $/$ & $/$ & 42.8 & $/$ & $/$ & $/$ & $/$ & $/$ & $/$ \\
\hline SD & $/$ & $/$ & 11.9 & 13.8 & $/$ & 14.7 & $/$ & 13.9 & 13.7 & 25.2 & $/$ \\
\hline Bd & 24.8 & $/$ & 24.1 & 25.2 & $/$ & 28.2 & 25.8 & 25.6 & 24.8 & 20.1 & 25.2 \\
\hline Dd & 19.8 & $/$ & 19.9 & 13.8 & $/$ & 27.9 & 19.1 & 21.7 & 21.2 & $/$ & 18.9 \\
\hline
\end{tabular}

\begin{tabular}{|c|c|c|c|}
\hline \multicolumn{4}{|c|}{ Astragalus } \\
\hline GLl & 29.7 & 29.5 & 28.8 \\
\hline GLm & 25.9 & 27.9 & 27.2 \\
\hline Dl & 17.9 & 16.1 & 16.9 \\
\hline Bd & 19.3 & 19.6 & 18.2 \\
\hline Withers' height $(\mathrm{cm})$ & 62.2 & 61.8 & 60.3 \\
\hline
\end{tabular}

\begin{tabular}{|c|c|}
\hline \multicolumn{2}{|c|}{ Radiale } \\
\hline GB & 19.2 \\
\hline
\end{tabular}




\begin{tabular}{|c|c|}
\hline \multicolumn{2}{|c|}{ Calcaneus } \\
\hline GL & 55.7 \\
\hline GB & 19.9 \\
\hline Withers' height $(\mathrm{cm})$ & 60 \\
\hline
\end{tabular}

\begin{tabular}{|c|c|c|c|c|}
\hline \multicolumn{5}{|c|}{ Metacarpus } \\
\hline Bp & 19.8 & 23.2 & 25.5 & 7 \\
\hline Dp & 18.7 & 16.5 & $/$ & $/$ \\
\hline SD & 12.9 & $/$ & 11.8 & $/$ \\
\hline Bd & 26.3 & $/$ & 17.5 & 26.6 \\
\hline Dd & $/$ & $/$ & $/$ & 15.4 \\
\hline
\end{tabular}

\begin{tabular}{|c|c|c|c|c|}
\hline \multicolumn{5}{|c|}{ Metatarsus } \\
\hline Bp & 19.8 & 19.4 & 22.7 & 21.1 \\
\hline Dp & 18.7 & 18.9 & 22 & 19.1 \\
\hline SD & 12.9 & 11.7 & 13.3 & 11.5 \\
\hline Bd & 26.3 & $/$ & $/$ & $/$ \\
\hline
\end{tabular}

\begin{tabular}{|c|c|c|c|c|}
\hline \multicolumn{5}{|c|}{ Capra hircus } \\
\hline \multicolumn{5}{|c|}{ Mandibula } \\
\hline $\mathrm{D}_{2}-\mathrm{D}_{4}$ & 1 & 29.3 & 31.4 & I \\
\hline $\mathrm{H}\left(\mathrm{D}_{2}\right)$ & I & 12.7 & 13.9 & l \\
\hline $\mathrm{L} \mathrm{D}_{4}$ & 1 & 16.7 & 17.9 & 1 \\
\hline $\mathrm{B} \mathrm{D}_{4}$ & 1 & 4.8 & 5.2 & 1 \\
\hline $\mathrm{P}_{2}-\mathrm{P}_{4}$ & 27.3 & 1 & 1 & 21.3 \\
\hline $\mathrm{H}\left(\mathrm{P}_{2}\right)$ & 16.2 & I & I & 15.8 \\
\hline $\mathrm{H}\left(\mathrm{M}_{1}\right)$ & 1 & 21.7 & 1 & 21.4 \\
\hline $\mathrm{L}\left(\mathrm{M}_{1}\right)$ & I & 14.1 & I & l \\
\hline$M_{1}-M_{3}$ & I & I & I & 37.3 \\
\hline
\end{tabular}




\begin{tabular}{|c|c|c|c|c|}
\hline $\mathrm{H}\left(\mathrm{M}_{3}\right)$ & $/$ & $/$ & $/$ & 72.9 \\
\hline $\mathrm{P}_{2}-\mathrm{M}_{3}$ & $/$ & $/$ & $/$ & 38.7 \\
\hline
\end{tabular}

\begin{tabular}{|c|c|}
\hline \multicolumn{2}{|c|}{ Horn core } \\
\hline Meas. 8 & 33.3 \\
\hline Meas. 9 & 22.4 \\
\hline
\end{tabular}

\begin{tabular}{|c|c|}
\hline \multicolumn{2}{|c|}{ Scapula } \\
\hline SLC & 17.5 \\
\hline GLP & 33.6 \\
\hline LG & 26.9 \\
\hline
\end{tabular}

\begin{tabular}{|c|c|c|}
\hline \multicolumn{3}{|c|}{ Humerus } \\
\hline $\mathrm{SD}$ & 14.1 & $/$ \\
\hline $\mathrm{Bd}$ & 31.6 & 29.9 \\
\hline $\mathrm{BT}$ & 30.4 & $/$ \\
\hline
\end{tabular}

\begin{tabular}{|c|c|c|}
\hline \multicolumn{3}{|c|}{ Ulna+Radius } \\
\hline DPA & 25.6 & $/$ \\
\hline Bp & 29.6 & 33.2 \\
\hline BFp & 28.5 & 31.9 \\
\hline BPC & $/$ & 25.5 \\
\hline
\end{tabular}

\begin{tabular}{|c|c|c|c|}
\hline \multicolumn{4}{|c|}{ Radius } \\
\hline GL & $/$ & 168.9 & $/$ \\
\hline Bp & 31.7 & 31.7 & 29.9 \\
\hline BFp & 29.9 & 31.3 & 28.7 \\
\hline SD & 19.7 & 18.5 & 15.8 \\
\hline Bd & $/$ & 29.9 & $/$ \\
\hline
\end{tabular}




\begin{tabular}{|c|c|c|c|}
\hline BFd & $/$ & 25.7 & $/$ \\
\hline Withers' height (cm) & $/$ & 67.2 & $/$ \\
\hline
\end{tabular}

\begin{tabular}{|c|c|}
\hline \multicolumn{2}{|c|}{ Femur } \\
\hline Bd & 36.1 \\
\hline Dd & 45.9 \\
\hline
\end{tabular}

\begin{tabular}{|c|c|c|c|}
\hline \multicolumn{4}{|c|}{ Tibia } \\
\hline Bp & 41.4 & $/$ & $/$ \\
\hline SD & $/$ & 14.5 & 13.4 \\
\hline Bd & $/$ & 23.9 & 24.7 \\
\hline Dd & $/$ & 20.5 & 17.9 \\
\hline
\end{tabular}

\begin{tabular}{|c|c|}
\hline \multicolumn{2}{|c|}{ Astragalus } \\
\hline $\mathrm{GLl}$ & 29.5 \\
\hline $\mathrm{GLm}$ & 27.6 \\
\hline $\mathrm{Dl}$ & 11.8 \\
\hline $\mathrm{Dm}$ & 16.9 \\
\hline
\end{tabular}

\begin{tabular}{|c|c|c|c|}
\hline \multicolumn{4}{|c|}{ Phalanx I } \\
\hline GLpe & 37.8 & 35.4 & $/$ \\
\hline Bp & 12.2 & 12.3 & $/$ \\
\hline $\mathrm{Dp}$ & $/$ & 14.4 & $/$ \\
\hline $\mathrm{SD}$ & 10.5 & 10.2 & 8.6 \\
\hline $\mathrm{Bd}$ & 11.2 & 11.5 & 9.7 \\
\hline $\mathrm{Dd}$ & $/$ & 10.4 & 9.2 \\
\hline
\end{tabular}




\begin{tabular}{|c|c|c|c|}
\hline \multicolumn{4}{|c|}{ Metacarpus } \\
\hline Bp & 24.8 & 24.8 & 25.7 \\
\hline Dp & 20.1 & 17.1 & 18.3 \\
\hline SD & 14.1 & 14.5 & 17.1 \\
\hline
\end{tabular}

Ovis/Capra

\begin{tabular}{|c|c|}
\hline \multicolumn{2}{|c|}{ Scapula } \\
\hline SLC & 19.2 \\
\hline LG & 20.3 \\
\hline BG & 21.8 \\
\hline
\end{tabular}

\begin{tabular}{|c|c|c|c|}
\hline \multicolumn{4}{|c|}{ Tibia } \\
\hline Bd & 21.8 & 21.4 & 25.3 \\
\hline Dd & 14.3 & 15.8 & 19.1 \\
\hline
\end{tabular}

\begin{tabular}{|c|c|}
\hline \multicolumn{2}{|c|}{ Femur } \\
\hline Dd & 42.8 \\
\hline
\end{tabular}

Sus domesticus

\begin{tabular}{|c|c|c|}
\hline \multicolumn{3}{|c|}{ Mandibula } \\
\hline $\mathrm{D}_{2}-\mathrm{D}_{4}$ & $/$ & 34.6 \\
\hline $\mathrm{H}\left(\mathrm{D}_{2}\right)$ & $/$ & 23.5 \\
\hline $\mathrm{L} \mathrm{D}_{4}$ & $/$ & 18.1 \\
\hline $\mathrm{B} \mathrm{D}_{4}$ & $/$ & 7.9 \\
\hline $\mathrm{L} \mathrm{M}_{3}$ & 29.2 & $/$ \\
\hline $\mathrm{B} \mathrm{M}_{3}$ & 15.1 & $/$ \\
\hline
\end{tabular}




\begin{tabular}{|c|c|}
\hline \multicolumn{2}{|c|}{$\mathrm{I}_{1}$} \\
\hline $\mathrm{L}$ & 50.2 \\
\hline $\mathrm{B}$ & 6.9 \\
\hline
\end{tabular}

\begin{tabular}{|c|c|c|}
\hline \multicolumn{3}{|c|}{ Scapula } \\
\hline SLC & 22.4 & 25.2 \\
\hline GLP & 30.8 & 36.2 \\
\hline LG & $/$ & 29.7 \\
\hline BG & 21.9 & 27.5 \\
\hline
\end{tabular}

\begin{tabular}{|c|c|c|}
\hline \multicolumn{3}{|c|}{ Humerus } \\
\hline Bd & 42.2 & 36.8 \\
\hline Dd & 42.1 & $/$ \\
\hline BT & 35.7 & 31.4 \\
\hline
\end{tabular}

\begin{tabular}{|c|c|c|}
\hline \multicolumn{3}{|c|}{ Radius } \\
\hline GL & 146.4 & $/$ \\
\hline Bp & 28.5 & 27.2 \\
\hline BFp & 28.1 & 26.9 \\
\hline Dp & 19.6 & $/$ \\
\hline SD & 17.2 & $/$ \\
\hline Bd & 32.9 & $/$ \\
\hline BFd & 29.1 & $/$ \\
\hline Dd & 24.3 & $/$ \\
\hline Withers' height (cm) & 77 & $/$ \\
\hline
\end{tabular}




\begin{tabular}{|c|c|}
\hline \multicolumn{2}{|c|}{ Ulna } \\
\hline DPA & 34.9 \\
\hline SDO & 26.7 \\
\hline BPC & 22.5 \\
\hline
\end{tabular}

\begin{tabular}{|c|c|c|}
\hline \multicolumn{3}{|c|}{ Femur } \\
\hline Bd & 41.2 & 51.3 \\
\hline Dd & 51.3 & 51.5 \\
\hline
\end{tabular}

\begin{tabular}{|c|c|}
\hline \multicolumn{2}{|c|}{ Tibia } \\
\hline Dp & 21.8 \\
\hline Bd & 25.7 \\
\hline Dd & 22.8 \\
\hline
\end{tabular}

\begin{tabular}{|c|c|c|}
\hline \multicolumn{3}{|c|}{ Metatarsus III } \\
\hline Bp & 13.2 & 16.8 \\
\hline Dp & 19.7 & 19.1 \\
\hline SD & 7.2 & 11.1 \\
\hline
\end{tabular}

Equus caballus

\begin{tabular}{|c|c|}
\hline \multicolumn{2}{|c|}{ Phalanx I } \\
\hline GL & 78.1 \\
\hline Bp & 51.7 \\
\hline BFp & 47.5 \\
\hline Dp & 35.1 \\
\hline SD & 34.1 \\
\hline Bd & 45.6 \\
\hline BFd & 42.3 \\
\hline Dd & 22.9 \\
\hline
\end{tabular}


Equus sp.

\begin{tabular}{|c|c|}
\hline \multicolumn{2}{|c|}{ Tibia } \\
\hline Bp & 89.8 \\
\hline
\end{tabular}

Canis familiaris

\begin{tabular}{|c|c|}
\hline \multicolumn{2}{|c|}{ Ulna } \\
\hline GL & 197.3 \\
\hline DPA & 28.1 \\
\hline BPC & 20.5 \\
\hline Withers' height $(\mathrm{cm})$ & 55.5 \\
\hline
\end{tabular}

\begin{tabular}{|c|c|}
\hline \multicolumn{2}{|c|}{ Radius } \\
\hline GL & 181.3 \\
\hline Bp & 19.6 \\
\hline SD & 14.1 \\
\hline Bd & 22.6 \\
\hline Withers' height $(\mathrm{cm})$ & 59.6 \\
\hline
\end{tabular}

Gallus domesticus

\begin{tabular}{|r|r|}
\hline \multicolumn{2}{|c|}{ Os coracoideus } \\
\hline $\mathrm{GL}$ & 45.5 \\
\hline $\mathrm{Lm}$ & 43.1 \\
\hline $\mathrm{Bf}$ & 10.3 \\
\hline $\mathrm{SD}$ & 4.2 \\
\hline
\end{tabular}




\begin{tabular}{|c|c|}
\hline \multicolumn{2}{|c|}{ Tibia } \\
\hline GL & 122.2 \\
\hline La & 118.7 \\
\hline Dip & 22.1 \\
\hline SC & 6.4 \\
\hline Bd & 12.5 \\
\hline Dd & 12.7 \\
\hline
\end{tabular}

\begin{tabular}{|c|c|}
\hline \multicolumn{2}{|c|}{ Tarsometatarsus } \\
\hline $\mathrm{Bp}$ & 13.6 \\
\hline $\mathrm{Dp}$ & 11.1 \\
\hline
\end{tabular}

\begin{tabular}{|c|c|c|}
\multicolumn{3}{|c|}{ Sus scrofa } \\
\hline \multicolumn{3}{|c|}{ Maxilla } \\
\hline $\mathrm{M}^{1}-\mathrm{M}^{3}$ & 80.3 & 84.3 \\
\hline $\mathrm{L} \mathrm{M}^{3}$ & 39.7 & 42.8 \\
\hline $\mathrm{B} \mathrm{M}^{3}$ & 24.1 & $/$ \\
\hline
\end{tabular}

\begin{tabular}{|l|l|}
\hline \multicolumn{2}{|c|}{ Atlas } \\
\hline BFcr & 67.1 \\
\hline
\end{tabular}

\begin{tabular}{|c|c|}
\hline \multicolumn{2}{|c|}{ Humerus } \\
\hline Bd & 56.3 \\
\hline Dd & 55.3 \\
\hline BT & 45.9 \\
\hline
\end{tabular}




\section{Cervus elaphus}

\begin{tabular}{|c|c|}
\hline \multicolumn{2}{|c|}{ Scapula } \\
\hline SLC & 37.1 \\
\hline LG & 36.2 \\
\hline BG & 34.4 \\
\hline
\end{tabular}

\begin{tabular}{|c|c|}
\hline \multicolumn{2}{|c|}{ Ulna } \\
\hline BPC & 36.3 \\
\hline
\end{tabular}

\section{Capreolus capreolus}

\begin{tabular}{|c|c|}
\hline \multicolumn{2}{|c|}{ Antler } \\
\hline Meas. 10 & 84.2 \\
\hline
\end{tabular}

\begin{tabular}{|c|c|}
\hline \multicolumn{2}{|c|}{ Scapula } \\
\hline SLC & 18.4 \\
\hline LG & 22.4 \\
\hline BG & 20.2 \\
\hline
\end{tabular}

Lepus europaeus
\begin{tabular}{|c|c|}
\hline \multicolumn{2}{|c|}{ Scapula } \\
\hline SLC & 7.1 \\
\hline GLP & 16.1 \\
\hline LG & 13.8 \\
\hline
\end{tabular}

